\title{
글
}

SYSTEMATIC REVIEW

\section{Should the restoration of adjacent implants be splinted or nonsplinted? A systematic review and meta-analysis}

\author{
Victor E. de Souza Batista, DDS, MSc, PhD, ${ }^{a}$ Fellippo R. Verri, DDS, MSc, PhD, ${ }^{b}$ Cleidiel A. A. Lemos, DDS, MSc, \\ Ronaldo S. Cruz, DDS, MSc, ${ }^{d}$ Hiskell F. F. Oliveira, DDS, MSc, ${ }^{e}$ Jéssica M. L. Gomes, DDS, and \\ Eduardo P. Pellizzer, DDS, MSc, PhD ${ }^{9}$
}

\begin{abstract}
Statement of problem. The decision to splint or to restore independently generally occurs during the planning stage, when the advantages and disadvantages of each clinical situation are considered based on the proposed treatment. However, clinical evidence to help clinicians make this decision is lacking.

Purpose. The purpose of this systematic review and meta-analysis was to assess the marginal bone loss, implant survival rate, and prosthetic complications of splinted and nonsplinted implant restorations.

Material and methods. This study was designed according to the Cochrane criteria for elaborating a systematic review and meta-analysis and adopted the Preferred Reporting Items for Systematic Reviews and Meta-analyses (PRISMA) statement. Also, this review was registered at the International Prospective Register of Systematic Reviews (PROSPERO) (CRD42017080162). An electronic search in the PubMed/MEDLINE, Cochrane Library, and Scopus databases was conducted up to November 2017. A specific clinical question was structured according to the population, intervention, comparison, outcome (PICO) approach. The addressed focused question was "Should the restoration of adjacent implants be splinted or nonsplinted?" The meta-analysis was based on the Mantel-Haenszel and inverse variance methods to assess the marginal bone loss, implant survival, and prosthetic complications of splinted and nonsplinted implant restorations.
\end{abstract}

Results. Nineteen studies were selected for qualitative and quantitative analyses. A total of 4215 implants were placed in 2185 patients (splinted, 2768; nonsplinted, 1447); the mean follow-up was 87.8 months (range=12-264 months). Quantitative analysis found no significant differences between splinted and nonsplinted restorations for marginal bone loss. The assessed studies reported that 75 implants failed (3.4\%), of which 24 were splinted (99.1\% of survival rate) and 51 were nonsplinted (96.5\% of survival rate). Quantitative analysis of all studies showed statistically significant higher survival rates for splinted restorations than for nonsplinted restorations. Ceramic chipping, screw loosening, abutment screw breakage, and soft tissue inflammation were reported in the selected studies. The quantitative analysis found no statistically significant difference in the prosthetic complications of splinted and nonsplinted restorations.

Conclusions. Within the limitations of this systematic review and meta-analysis, it was concluded that there was no difference in the marginal bone loss and prosthetic complications of splinted and nonsplinted implant restorations; this is especially true for restorations in the posterior region. However, splinted restorations were associated with decreased implant failure. (J Prosthet Dent 2019;121:41-51)

\footnotetext{
Supported by grant 2015/07383-8 from the São Paulo Research Foundation, Brazil.

${ }^{a}$ Associate Professor, Department of Prosthodontics, Presidente Prudente Dental School, University of Western São Paulo (UNOESTE), Presidente Prudente, Brazil.

${ }^{\mathrm{b}}$ Adjunct Professor, Department of Dental Materials and Prosthodontics, Araçatuba Dental School, São Paulo State University (UNESP), Araçatuba, Brazil.

${ }^{c}$ Doctoral student, Department of Dental Materials and Prosthodontics, Araçatuba Dental School, São Paulo State University (UNESP), Araçatuba, Brazil.

${ }^{d}$ Doctoral student, Department of Dental Materials and Prosthodontics, Araçatuba Dental School, São Paulo State University (UNESP), Araçatuba, Brazil.

eDoctoral student, Department of Dental Materials and Prosthodontics, Araçatuba Dental School, São Paulo State University (UNESP), Araçatuba, Brazil.

fGraduate student, Department of Dental Materials and Prosthodontics, Araçatuba Dental School, São Paulo State University (UNESP), Araçatuba, Brazil.

${ }^{g}$ Full Professor, Department of Dental Materials and Prosthodontics, Araçatuba Dental School, São Paulo State University (UNESP), Araçatuba, Brazil.
} 


\section{Clinical Implications}

Studies comparing splinted and nonsplinted restorations supported by implants suggest that splinted restorations provide a greater margin of safety in avoiding implant failure.

Dental implants have been used frequently to support prostheses for patients with partial edentulism and have shown high survival rates. ${ }^{1,2}$ However, they are susceptible to biological and mechanical complications ranging from marginal bone loss to loss of the implant. . $^{1,3}$ Peri-implant bone loss has been related to surgical trauma, peri-implantitis, occlusal overload, biologic width formation, implant macroscopic characteristics at the neck region in contact with the bone, implant-abutment interface design, and position of the microgap ${ }^{4}$; consequently, the control of these factors is essential to treatment success.

Clinicians are unclear as to whether the rehabilitation of adjacent implants should be splinted or not, and the literature suggests that implant length, occlusion, oral hygiene, abutment connection design, and difficulty achieving a passively fitting framework must be considered. ${ }^{5}$ Some biomechanical studies have suggested that splinted restorations offer load sharing among the components of the rehabilitation and decrease the stress on cortical bone $\mathrm{e}^{5-8}$; whereas single-unit restorations (nonsplinted) facilitate oral hygiene, provide better passivity of the framework, and allow restorations with improved emergence profiles and cervical contours. 5,9,10

Clelland et $\mathrm{al}^{5}$ reported results of a split-mouth study in which peri-implant bone levels around splinted and nonsplinted restorations supported by implants were not statistically different for internal connection implants greater than $6 \mathrm{~mm}$ in length, but screw loosening occurred only on the nonsplinted rehabilitation. However, Vigolo et $\mathrm{al}^{4}$ showed with a randomized controlled trial that splinted restorations supported by external hexagon implants (diameter $=4 \times 10$ to $13 \mathrm{~mm}$ ) showed mean bone loss of 0.7 $\mathrm{mm}$ and that the nonsplinted restorations showed mean bone loss of $0.8 \mathrm{~mm}$ after a 5 -year follow-up; the same amount of difference $(0.1 \mathrm{~mm})$ was maintained until the last follow-up (after 10 years), reaching 1.2 $\mathrm{mm}$ and $1.3 \mathrm{~mm}$, respectively.

In summary, clinicians who read the published literature in the hope of discovering a clear-cut answer regarding the appropriate technique to adopt in the prosthetic treatment of adjacent implants (splinted or not) will find conflicting results. Indeed, the current literature does not provide even minimal clinical evidence

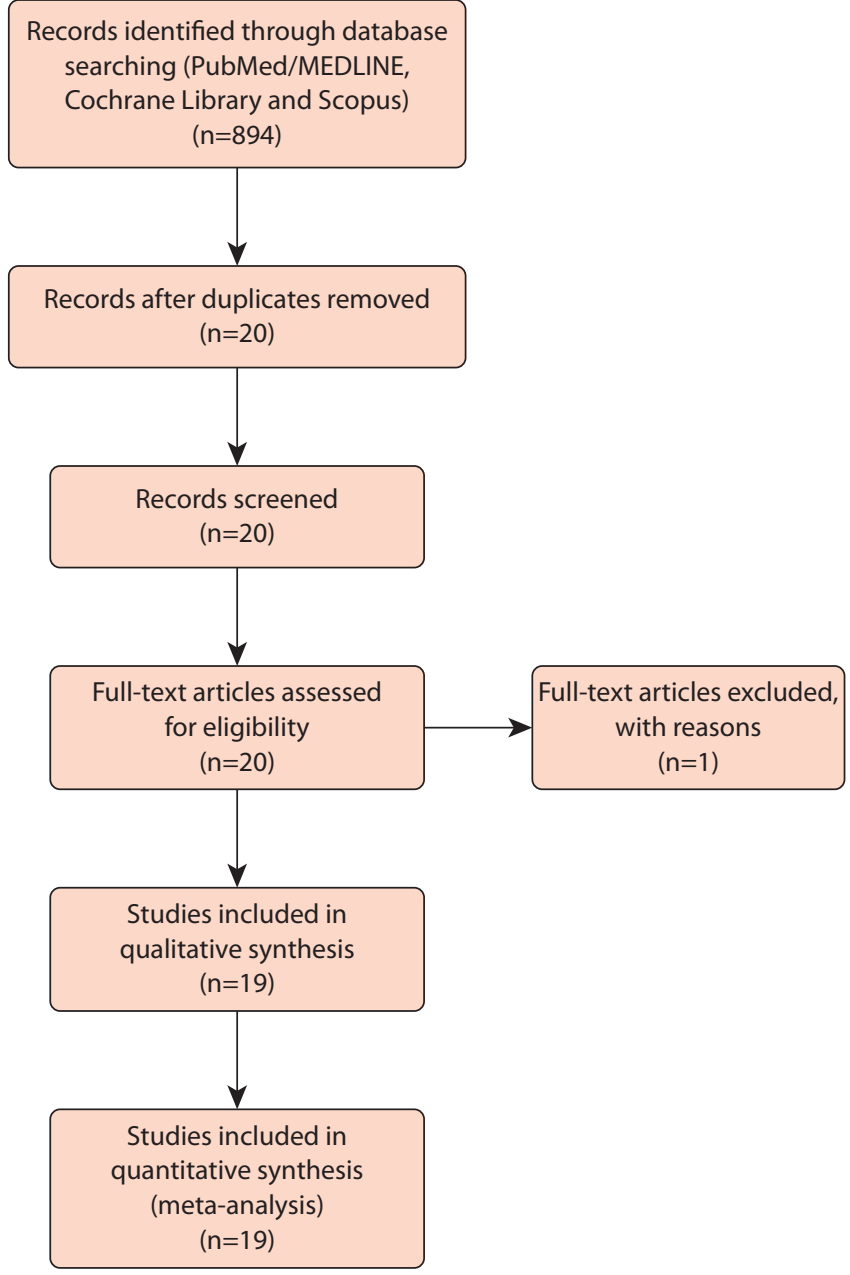

Figure 1. Study design.

to help clinicians make this decision ${ }^{5}$ and does not contain a clear guide to correct prosthetic planning. Therefore, the purpose of this systematic review and meta-analysis was to assess the marginal bone loss, implant survival rate, and prosthetic complications of splinted and nonsplinted implant restorations. The null hypotheses of this study were that no differences would be found between splinted and nonsplinted implant restorations regarding marginal bone loss and that no differences would be found in relation to the implant survival rates and prosthetic complications of splinted and nonsplinted implant restorations.

\section{MATERIAL AND METHODS}

This study was designed according to the Cochrane criteria (Cochrane Handbook for Systematic Reviews of Interventions, v5.1.0) ${ }^{11}$ for conducting a systematic review and meta-analysis and adopted the Preferred Reporting Items for Systematic Reviews and Metaanalyses (PRISMA) statement. ${ }^{12}$ Also, this review was 
Table 1. Summary of studies selected

\begin{tabular}{|c|c|c|c|c|c|c|c|c|c|}
\hline $\begin{array}{l}\text { Study and Year } \\
\text { of Publication }\end{array}$ & $\begin{array}{c}\text { Patients, } \\
\text { N }\end{array}$ & $\begin{array}{c}\text { Mean } \\
\text { Age, } y\end{array}$ & Implants, n & $\begin{array}{c}\text { No. of } \\
\text { Splinted (S) and } \\
\text { Nonsplinted (NS) } \\
\text { Implants }\end{array}$ & $\begin{array}{c}\text { Length of } \\
\text { Follow-Up, } \\
\text { mo }\end{array}$ & $\begin{array}{c}\text { Mean (SD) } \\
\text { Marginal Bone } \\
\text { Loss Over } \\
\text { Follow-up Period, } \mathrm{mm}\end{array}$ & $\begin{array}{c}\text { Lost } \\
\text { Implant, } \mathbf{n}\end{array}$ & $\begin{array}{c}\text { Lost } \\
\text { Prosthesis, } \mathbf{n}\end{array}$ & $\begin{array}{c}\text { Prosthetic } \\
\text { Complication, } \mathbf{n}\end{array}$ \\
\hline Maló et al $2003^{19}$ & 76 & 41 & 103 & $\begin{array}{l}\text { S: } 52 \\
\text { NS: } 51\end{array}$ & 12 & NR & $\begin{array}{l}\text { S: } 1 \\
\text { NS: } 4\end{array}$ & NR & NR \\
\hline Rocci et al $2003^{20}$ & 46 & 51 & 97 & $\begin{array}{l}\text { S: } 70 \\
\text { NS: } 27\end{array}$ & 36 & NR & $\begin{array}{l}\text { S: } 3 \\
\text { NS: } 5\end{array}$ & NR & NR \\
\hline Rokni et al $2005^{21}$ & 74 & 53 & 199 & $\begin{array}{l}\text { S: } 76 \\
\text { NS: } 123\end{array}$ & 60 & $\begin{array}{l}\text { S: }-0.5(0.4) \\
\text { NS: - }-0.3(0.4)\end{array}$ & NR & 0 & $\begin{array}{l}\text { S: } 0 \\
\text { NS: } 0\end{array}$ \\
\hline Bilhan et al $2010^{22}$ & 36 & 54.97 & 126 & $\begin{array}{l}\text { S: } 106 \\
\text { NS: } 20\end{array}$ & 36 & $\begin{array}{l}\text { Distal } \\
\text { S: } 0.99(0.15) \\
\text { NS: } 0.96(0.19) \\
\text { Mesial } \\
\text { S: } 0.97(0.14) \\
\text { NS: } 0.94(0.26)\end{array}$ & NR & NR & $\begin{array}{l}\text { S: } 0 \\
\text { NS: } 0\end{array}$ \\
\hline Sohn et al $2010^{23}$ & 43 & 55.8 & 122 & $\begin{array}{l}\text { S: } 103 \\
\text { NS: } 19\end{array}$ & 108 & NR & $\begin{array}{l}\text { S: } 2 \\
\text { NS: } 1\end{array}$ & NR & NR \\
\hline $\begin{array}{l}\text { Vigolo and Zaccaria } \\
2010^{24}\end{array}$ & 44 & 51 & 123 & $\begin{array}{l}\text { S: } 63 \\
\text { NS: } 60\end{array}$ & 60 & $\begin{array}{l}\text { S: }-0.7(0.2) \\
\text { NS: }-0.8(0.2)\end{array}$ & NR & NR & $\begin{array}{l}\text { S: } 0 \\
\text { NS: } 0\end{array}$ \\
\hline Perelli et al $2011^{25}$ & 40 & NR & 50 & $\begin{array}{l}\text { S: } 29 \\
\text { NS: } 21\end{array}$ & 60 & NR & $\begin{array}{l}\text { S: } 3 \\
\text { NS: } 4\end{array}$ & $\begin{array}{l}\text { S: } 0 \\
\text { NS: } 4\end{array}$ & NR \\
\hline Perelli et al $2012^{26}$ & 87 & NR & 110 & $\begin{array}{l}\text { S: } 47 \\
\text { NS: } 63\end{array}$ & 60 & NR & $\begin{array}{l}\text { S: } 3 \\
\text { NS: } 6\end{array}$ & $\begin{array}{l}\text { S: } 0 \\
\text { NS: } 6\end{array}$ & $3^{\mathrm{a}}$ \\
\hline Rodrigo et al $2013^{27}$ & 159 & NR & 223 & $\begin{array}{l}\text { S: } 209 \\
\text { NS: } 14\end{array}$ & 72 & NR & $\begin{array}{l}\text { S: } 1 \\
\text { NS: } 1\end{array}$ & NR & NR \\
\hline Sivolella et al $2013^{28}$ & NC & NR & 50 & $\begin{array}{l}\text { S: } 20 \\
\text { NS: } 30\end{array}$ & 192 & NC & NC & $\mathrm{NC}$ & $\begin{array}{l}\text { S: } 15 \\
\text { NS: } 6\end{array}$ \\
\hline Vanlıoğlu et al $2013^{29}$ & 95 & 41.2 & 231 & $\begin{array}{l}\text { S: } 106 \\
\text { NS: } 125\end{array}$ & 120 & NR & NR & $\begin{array}{l}\text { S: } 2 \\
\text { NS: } 2\end{array}$ & $\begin{array}{l}\text { S: } 4 \\
\text { NS: } 3\end{array}$ \\
\hline Wagenberg et al $2013^{30}$ & 541 & 58.75 & 1187 & $\begin{array}{l}\text { S: } 970 \\
\text { NS: } 217\end{array}$ & 264 & $\begin{array}{l}\text { S: } 0.44(0.6813) \\
\text { NS: } 0.55(0.8551)\end{array}$ & NR & NR & NR \\
\hline Mendonça et al $2014^{31}$ & 198 & 60.45 & 453 & $\begin{array}{l}\text { S: } 219 \\
\text { NS: } 234\end{array}$ & 192 & $\begin{array}{l}\text { S: } 1.22(0.95) \\
\text { NS: } 1.27(1.15)\end{array}$ & $\begin{array}{l}\text { S: } 5 \\
\text { NS: } 16\end{array}$ & NR & NR \\
\hline Sohn et al $2014^{32}$ & 42 & NR & 84 & $\begin{array}{l}\text { S: } 69 \\
\text { NS: } 15\end{array}$ & 108 & NR & $\begin{array}{l}\text { S: } 6 \\
\text { NS: } 2\end{array}$ & NR & NR \\
\hline $\begin{array}{l}\text { Wagenberg and } \\
\text { Froum } 2015^{33}\end{array}$ & 312 & NR & 312 & $\begin{array}{l}\text { S: } 240 \\
\text { NS: } 72\end{array}$ & 144 & $\begin{array}{l}\text { S: } 0.5(0.8) \\
\text { NS: } 0.3(0.65)\end{array}$ & NR & NR & NR \\
\hline $\begin{array}{l}\text { Ghaleh Golab } \\
\text { et al } 2015^{34}\end{array}$ & 272 & 56.3 & $469 \$$ & $\begin{array}{l}\text { S: } 232 \\
\text { NS: } 237\end{array}$ & 12 & NR & $\begin{array}{l}\text { S: } 0 \\
\text { NS: } 11\end{array}$ & NR & NR \\
\hline Vigolo et al $2015^{4}$ & 38 & 51 & 114 & $\begin{array}{l}\text { S: } 60 \\
\text { NS: } 54\end{array}$ & 120 & $\begin{array}{l}\text { S: } 1.2(0.2) \\
\text { NS: } 1.3(0.2)\end{array}$ & $\begin{array}{l}\text { S: } 0 \\
\text { NS: } 0\end{array}$ & NR & $\begin{array}{l}\text { S: } 0 \\
\text { NS: } 0\end{array}$ \\
\hline Clelland et al $2016^{5}$ & 15 & 56 & 64 & $\begin{array}{l}\text { S: } 32 \\
\text { NS: } 32\end{array}$ & 36 & $\begin{array}{l}\text { Machined bevel } \\
\text { surface: } \\
\text { S: } 0.68(0.82) \\
\text { NS: } 0.44(0.58) \\
\text { Machined bevel } \\
\text { surface: } \\
\text { S: } 0.52(0.64) \\
\text { NS: } 0.14(0.22)\end{array}$ & $\begin{array}{l}\text { S: } 0 \\
\text { NS: } 1\end{array}$ & $\begin{array}{l}\text { S: } 0 \\
\text { NS: } 0\end{array}$ & $\begin{array}{l}\text { S: } 1 \\
\text { NS: } 5\end{array}$ \\
\hline Shi et al $2017^{36}$ & 67 & 38.29 & 98 & $\begin{array}{l}\text { S: } 65 \\
\text { NS: } 33\end{array}$ & 96 & $\begin{array}{l}\text { S: } 1.22(0.81)^{b} \\
\text { NS: } 1.10(1.47)^{c}\end{array}$ & NR & NR & $\begin{array}{l}\text { S: } 10 \\
\text { NS: } 13\end{array}$ \\
\hline
\end{tabular}

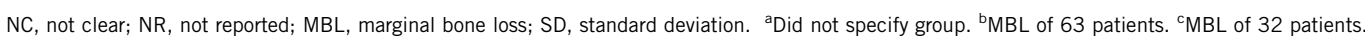

registered at the International Prospective Register of Systematic Reviews (PROSPERO) (CRD42017080162).

The inclusion criteria were randomized controlled trials, prospective studies, retrospective studies, clinical human studies, studies that compared crestal bone loss around splinted and nonsplinted restorations supported by implants, studies that offered information about the implant survival of splinted and nonsplinted implantsupported restorations, studies with a follow-up of more than 6 months, and studies published in the English language. Exclusion criteria included any articles that failed to meet the inclusion criteria and studies that evaluated the splinting of implant-supported completearch prostheses.

A specific clinical question was structured according to the population, intervention, comparison, outcome (PICO) approach. The addressed focused question was "Should the restoration of adjacent implants be splinted or nonsplinted?" In this process, P represented patients treated with dental implants; I, patients with nonsplinted restorations supported by implants; C, compared with patients with splinted 
Table 2. Characteristics of studies selected

\begin{tabular}{|c|c|c|c|c|c|c|c|c|c|}
\hline Study & Year & $\begin{array}{l}\text { Design } \\
\text { of Study }\end{array}$ & $\begin{array}{c}\text { Setting } \\
\text { of Studies }\end{array}$ & $\begin{array}{l}\text { Implant System/ } \\
\text { Connection Type }\end{array}$ & $\begin{array}{l}\text { Diameter/ } \\
\text { length }(\mathbf{m m})\end{array}$ & $\begin{array}{l}\text { Implants in } \\
\text { Each Arch, } n\end{array}$ & $\begin{array}{l}\text { Localization, } \\
\mathbf{n}\end{array}$ & $\begin{array}{l}\text { Type of } \\
\text { Prostheses/ } \\
\text { Type of } \\
\text { Retention }\end{array}$ & $\begin{array}{l}\text { Prosthetic } \\
\text { Complications } \\
\text { Reported }\end{array}$ \\
\hline $\begin{array}{l}\text { Maló } \\
\text { et } \mathrm{al}^{19}\end{array}$ & 2003 & Prospective & Multicenter & $\begin{array}{l}\text { Brånemark System } \\
\text { Standard, } \\
\text { Mk II, Mk III, Mk IV } \\
\text { (Nobel Biocare AB)/ } \\
\text { external connection }\end{array}$ & $3.3-5 / 11-20$ & $\begin{array}{l}\text { Maxilla: } 74^{\mathrm{a}} \\
\text { Mandible: } 42^{\mathrm{a}}\end{array}$ & $\mathrm{NC}$ & All ceramic/NR & NR \\
\hline $\begin{array}{l}\text { Rocci } \\
\text { et } \mathrm{al}^{20}\end{array}$ & 2003 & Retrospective & NC & $\begin{array}{l}\text { Brånemark System Mk IV } \\
\text { (Nobel Biocare } A B) / \\
\text { external connection }\end{array}$ & $3.3-5 / 8.5-18$ & Maxilla: 97 & $\begin{array}{l}\text { Anterior: } 30 \\
\text { Posterior: } 67\end{array}$ & $\begin{array}{l}\mathrm{NR} / \text { cement } \\
\text { retained }\end{array}$ & NR \\
\hline $\begin{array}{l}\text { Rokni } \\
\text { et } \mathrm{al}^{21}\end{array}$ & 2005 & Prospective & NR & $\begin{array}{l}\text { Endopore dental implant } \\
\text { system (Innova } \\
\text { LifeSciences)/external } \\
\text { connection }^{\text {b }}\end{array}$ & $\begin{array}{l}3.5,4.1 \\
\text { and } 5.0 / \\
5,7,9, \\
\text { and } 12\end{array}$ & $\begin{array}{l}\text { Maxilla: } 151 \\
\text { Mandible: } 48\end{array}$ & $\begin{array}{l}\text { Anterior: } 35 \\
\text { Posterior: } 164\end{array}$ & $\begin{array}{l}\text { Metal-ceramic }{ }^{\mathrm{b}} / \\
\text { screw retained }\end{array}$ & NR \\
\hline $\begin{array}{l}\text { Bilhan } \\
\text { et } \mathrm{al}^{22}\end{array}$ & 2010 & Retrospective & University & $\begin{array}{l}\text { Straumann-Zimmer } \\
\text { Dental and Astra } \\
\text { Tech-Bio Lok-BioHorizons } \\
\text { /internal connection }\end{array}$ & NR & NC & NC & $\begin{array}{l}\mathrm{NR} / \text { cement } \\
\text { retained }\end{array}$ & NR \\
\hline $\begin{array}{l}\text { Sohn } \\
\text { et } \mathrm{al}^{23}\end{array}$ & 2010 & Retrospective & $\begin{array}{l}\text { Private and } \\
\text { university }\end{array}$ & $\begin{array}{l}\text { Endopore } \\
\text { (Innova Life Sciences)/NR }\end{array}$ & $\begin{array}{l}4.1, \text { and } \\
5.0 / 5,7,9, \\
\text { and } 12\end{array}$ & Mandible: 122 & Posterior: 122 & NR/NR & NR \\
\hline $\begin{array}{l}\text { Vigolo and } \\
\text { Zaccaria }^{24}\end{array}$ & 2010 & Prospective & University & $\begin{array}{l}\text { Biomet } 3 \mathrm{i} / \\
\text { external connection }\end{array}$ & $\begin{array}{l}4.0 / 10 \\
11.5,13\end{array}$ & Maxilla: 123 & Posterior: 123 & $\begin{array}{l}\text { Metal-ceramic/ } \\
\text { cement retained }\end{array}$ & $\begin{array}{l}\text { No patient reported any } \\
\text { prosthetic complications. }\end{array}$ \\
\hline $\begin{array}{l}\text { Perelli } \\
\text { et } \mathrm{al}^{25}\end{array}$ & 2011 & Prospective & NR & $\begin{array}{l}\text { Endopore } \\
\text { (Innova LifeSciences)/ } \\
\text { internal connection }^{\mathrm{b}}\end{array}$ & $\begin{array}{l}4.1 \text { and } 5.0 / \\
5 \text { and } 7\end{array}$ & Mandible: 50 & Posterior: 50 & $\begin{array}{l}\text { Metal-ceramic }{ }^{\mathrm{b}} / \\
\text { cement and screw } \\
\text { retained }\end{array}$ & $\begin{array}{l}\text { In } 4 \text { cases of single } \\
\text { crowns, prosthesis } \\
\text { failed; in remaining } \\
\text { cases, prostheses } \\
\text { could still be used without } \\
\text { being replaced. }\end{array}$ \\
\hline $\begin{array}{l}\text { Perelli } \\
\text { et } \mathrm{al}^{26}\end{array}$ & 2012 & Prospective & NR & $\begin{array}{l}\text { Endopore } \\
\text { (Innova LifeSciences)/ } \\
\text { internal connection }^{\mathrm{b}}\end{array}$ & $\begin{array}{l}4.1 \text { and } 5.0 / \\
5 \text { and } 7\end{array}$ & Maxilla: 110 & Posterior: 110 & $\begin{array}{l}\text { Metal-ceramic }{ }^{\mathrm{b}} / \\
\text { cement and } \\
\text { screw retained }\end{array}$ & $\begin{array}{l}\text { Two abutments became } \\
\text { unscrewed after } 3 \text { and } 4 \\
\text { years of function and one } \\
\text { ceramic chipping was } \\
\text { noticed in metal-ceramic } \\
\text { fixed dental prosthesis, } \\
\text { but author did not specify } \\
\text { group. No implant, } \\
\text { abutment, or screw fracture } \\
\text { occurred. Nine implants } \\
\text { failed and were removed. } \\
\text { Six were loaded with single } \\
\text { crowns and therefore } \\
\text { prostheses failed; } 3 \text { were } \\
\text { splinted to adjacent } \\
\text { implants and those } \\
\text { prostheses did not fail }\end{array}$ \\
\hline $\begin{array}{l}\text { Rodrigo } \\
\text { et } \mathrm{al}^{27}\end{array}$ & 2013 & Retrospective & Multicenter & $\begin{array}{l}\text { SLA-surfaced implants } \\
\text { (Straumann)/ } \\
\text { internal connection }^{\text {b }}\end{array}$ & $\begin{array}{l}4.1 \text { and } \\
4.8 / 6\end{array}$ & $\begin{array}{l}\text { Maxilla: } 16 \\
\text { Mandible: } 207\end{array}$ & $\begin{array}{l}\text { Anterior: } 2 \\
\text { Posterior: } 221\end{array}$ & $\begin{array}{l}\text { Metal-ceramic }^{\mathrm{b}} / \\
\text { cement and } \\
\text { screw retained }^{\mathrm{b}}\end{array}$ & $\begin{array}{l}\text { A single implant in } \\
\text { free-end situation failed } \\
3 \text { weeks after loading. } \\
\text { The other implant was } \\
\text { splinted to a longer } \\
\text { implant and failed after } \\
32 \text { months of function } \\
\text { because of peri-implantitis } \\
\text { in patient who smoked } \\
\text { and failed to keep } \\
\text { maintenance } \\
\text { appointments. }\end{array}$ \\
\hline $\begin{array}{l}\text { Sivolella } \\
\text { et } \mathrm{al}^{28}\end{array}$ & 2013 & Retrospective & University & $\begin{array}{l}\text { Biomet } 3 \mathrm{i} \text { and } \\
\text { Osseotite (Biomet 3i)/NC }\end{array}$ & $\begin{array}{l}3.75 \text { and } 4.0 / \\
7 \text { and } 8.5\end{array}$ & Mandible: 50 & NC & $\begin{array}{l}\mathrm{NR} / \text { cement } \\
\text { retained }\end{array}$ & $\begin{array}{l}\text { S: } 15 \text { veneer chippings } \\
\text { NS: } 2 \text { veneer chippings, } \\
2 \text { abutment screws } \\
\text { worked loose, and } 2 \\
\text { abutment screw } \\
\text { breakages }\end{array}$ \\
\hline $\begin{array}{l}\text { Vanlıoğlu } \\
\text { et } \mathrm{al}^{29}\end{array}$ & 2013 & Retrospective & University & $\begin{array}{l}\text { Straumann/ } \\
\text { internal connection }\end{array}$ & NR & $\begin{array}{l}\text { Maxilla: } 72^{c} \\
\text { Mandible: } 105^{c}\end{array}$ & $\mathrm{NC}$ & $\begin{array}{l}\text { metal-ceramic/ } \\
\text { cement retained }\end{array}$ & $\begin{array}{l}\text { S: } 4 \text { porcelain fractures } \\
\text { NS: } 3 \text { porcelain fractures }\end{array}$ \\
\hline $\begin{array}{l}\text { Wagenberg } \\
\text { et } \mathrm{al}^{30}\end{array}$ & 2013 & Retrospective & NR & NR & $\begin{array}{c}3.75,4.0,5.0 \\
\text { and } 6.0 / \mathrm{NR}\end{array}$ & $\mathrm{NC}$ & $\begin{array}{l}\text { Anterior: } 471 \\
\text { Posterior: } 716\end{array}$ & $\mathrm{NR} / \mathrm{NC}$ & NR \\
\hline
\end{tabular}


Table 2. (Continued) Characteristics of studies selected

\begin{tabular}{|c|c|c|c|c|c|c|c|c|c|}
\hline Study & Year & $\begin{array}{l}\text { Design } \\
\text { of Study }\end{array}$ & $\begin{array}{c}\text { Setting } \\
\text { of Studies }\end{array}$ & $\begin{array}{l}\text { Implant System/ } \\
\text { Connection Type }\end{array}$ & $\begin{array}{l}\text { Diameter/ } \\
\text { length }(\mathbf{m m})\end{array}$ & $\begin{array}{l}\text { Implants in } \\
\text { Each Arch, } \mathbf{n}\end{array}$ & $\begin{array}{c}\text { Localization, } \\
\mathbf{n}\end{array}$ & $\begin{array}{l}\text { Type of } \\
\text { Prostheses/ } \\
\text { Type of } \\
\text { Retention }\end{array}$ & $\begin{array}{l}\text { Prosthetic } \\
\text { Complications } \\
\text { Reported }\end{array}$ \\
\hline $\begin{array}{l}\text { Mendonça } \\
\text { et } \mathrm{al}^{31}\end{array}$ & 2014 & Retrospective & University & $\begin{array}{l}\text { NR/internal and } \\
\text { external connection }\end{array}$ & $\begin{array}{l}4.1 \text { and } 5.0 / \\
7,8.5, \text { and } 10\end{array}$ & $\begin{array}{l}\text { Maxilla: } 60 \\
\text { Mandible: } 393\end{array}$ & Posterior: 453 & $\begin{array}{l}\text { Metal-ceramic/ } \\
\text { NR }\end{array}$ & NR \\
\hline Sohn et $\mathrm{al}^{32}$ & 2014 & Retrospective & University & $\begin{array}{l}\text { Endopore } \\
\text { (Innova } \\
\text { LifeSciences)/NR }\end{array}$ & $\begin{array}{l}4.1 \text { and } 5.0 / \\
7,9, \text { and } 12\end{array}$ & Maxilla: 84 & Posterior: 84 & NR/NR & NR \\
\hline $\begin{array}{l}\text { Wagenberg } \\
\text { and Froum } \\
\end{array}$ & 2015 & Retrospective & $N R$ & NR & $\begin{array}{l}3.75,4.0,5.0 \\
\text { and } 6.0 / \mathrm{NR}\end{array}$ & $\mathrm{NC}$ & $\mathrm{NC}$ & $\mathrm{NC} / \mathrm{NC}$ & NR \\
\hline $\begin{array}{l}\text { Ghaleh } \\
\text { Golab et } \mathrm{al}^{34}\end{array}$ & 2015 & Prospective & Multicenter & $\begin{array}{l}\text { OPS implants } \\
\text { (S\&S Biomat)/ } \\
\text { one piece }\end{array}$ & $\begin{array}{l}\text { 3.0, } 3.4, \text { and } \\
4.0 / 8,11,13, \\
\text { and } 15\end{array}$ & $\mathrm{NC}$ & NC & $\begin{array}{l}\text { Metal-ceramic/ } \\
\text { cement } \\
\text { retained }\end{array}$ & $\begin{array}{l}2 \text { ceramic fracture, } 18 \\
\text { interim crown fractures, } \\
23 \text { interim crown } \\
\text { mobility, } 4 \text { cases of } \\
\text { soft tissue inflammation }\end{array}$ \\
\hline Vigolo et $\mathrm{al}^{4}$ & 2015 & $\mathrm{RCT}$ & $\begin{array}{l}\text { Private and } \\
\text { university }\end{array}$ & $\begin{array}{l}\text { Biomet-3i/ } \\
\text { external connection }\end{array}$ & $\begin{array}{c}3.0,3.4 \\
\text { and } 4.0 / 10, \\
11.5, \text { and } 13\end{array}$ & Maxilla: 114 & Posterior: 114 & $\begin{array}{l}\text { Metal-ceramic/ } \\
\text { cement retained }\end{array}$ & Without complications \\
\hline $\begin{array}{l}\text { Clelland } \\
\text { et } \mathrm{al}^{5}\end{array}$ & 2016 & Prospective & University & $\begin{array}{l}\text { OsseoSpeed } \\
\text { (Dentsply Sirona) } \\
\text { /internal connection }\end{array}$ & $\begin{array}{l}3.5,4, \text { and } 5 / \\
6,8,9 \text {, and } 11\end{array}$ & NC & Posterior: 82 & $\begin{array}{l}\text { Metal (gold) and } \\
\text { metal-ceramic/ } \\
\text { cement and } \\
\text { screw retained }^{\text {d }}\end{array}$ & $\begin{array}{l}\text { S: } 1 \text { case of } \\
\text { porcelain chipping } \\
\text { NS: } 5 \text { cases of } \\
\text { screw loosening }\end{array}$ \\
\hline Shi et $\mathrm{al}^{36}$ & 2017 & Retrospective & Hospital & $\begin{array}{l}\text { Straumann Standard } \\
\text { SLA implants/ } \\
\text { internal connection }\end{array}$ & $3.3 / 10$ and 12 & $\begin{array}{l}\text { Maxilla: } 42 \\
\text { Mandible: } 56\end{array}$ & Posterior: 98 & $\begin{array}{l}\text { Metal-ceramic/ } \\
\text { cemented } \\
\text { retained }\end{array}$ & $\begin{array}{l}\text { S: } 10 \text { ceramic chipping } \\
\text { NS: } 5 \text { losses of retention, } \\
8 \text { ceramic chipping }\end{array}$ \\
\hline
\end{tabular}

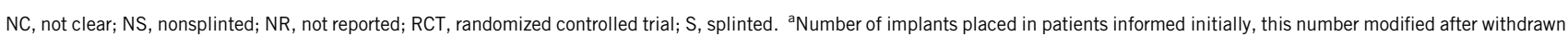

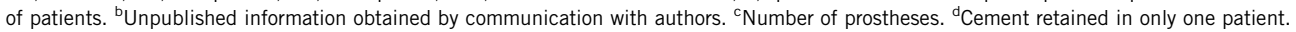

restorations supported by implants; and $\mathrm{O}$, overall marginal bone loss as the primary outcome to be extracted and analyzed in the meta-analysis. The survival rate of the implant and prosthetic complications were secondary outcomes.

An electronic search in the PubMed/MEDLINE, Cochrane Library, and Scopus databases was conducted until November 2017. Furthermore, a manual search was conducted to identify registered trials not yet published as of 2017 from the following journals: Clinical Oral Implants Research, Clinical Implant Dentistry and Related Research, International Journal of Oral and Maxillofacial Implants, International Journal of Oral and Maxillofacial Surgery, Journal of Oral and Maxillofacial Surgery, International Journal of Prosthodontics, Journal of Dental Research, Journal of Dentistry, Journal of Oral Rehabilitation, Journal of Prosthodontics, The International Journal of Prosthodontics, and The Journal of Prosthetic Dentistry.

Two researchers (V.E.S.B., C.A.A.L.) searched the selected electronic databases independently. The search terms used were as follows: splinted and dental implant OR nonsplinted and dental implant OR nonsplinted and dental implant.

Two researchers (V.E.S.B., C.A.A.L.) independently selected the studies according to their titles and abstracts and classified them as included or excluded. Any disagreements were settled through discussion and consensus with a third researcher (F.R.V.). The articles selected for inclusion were then read by both investigators, and the reference list was manually searched.
The full text of the selected articles was analyzed. The analysis of these selected articles was used to answer the PICO questions. The researcher (V.E.S.B.) collected relevant information from the articles, including authors, number of participants, mean age of participants, total of implants, number of implants for splinted and nonsplinted, range of follow up, mean of marginal bone loss over follow-up period for each group, number of implant loss and percentage of implant survival for each group, percentage of prosthesis survival, number of prosthetic complications, year of study, design of study, setting of study, implant system and connection type used in each study, diameter and length of implant in each study, number of implants in each arch, location of implant (anterior or posterior), type of prosthesis and type of retention, and prosthetic complications reported in each study. Another researcher (R.S.C.) then checked all the collected information. Any disagreements between the investigators were discussed with another researcher (E.P.P.) until consensus was reached. Duplicate-subject publications within separate unique studies were not reported twice.

The risk of bias assessment in the included randomized controlled trials (RCTs) was evaluated using the Cochrane Collaboration Tool for Assessing Risk of Bias in Randomized Trials. ${ }^{11}$ The assessment criteria were a domainbased evaluation in which critical assessments were made separately for different domains: random sequence generation, allocation concealment, blinding of participants and personnel, blinding of outcome assessment, 
incomplete outcome data, selective reporting, and other bias. ${ }^{11}$ For each domain, the risk of bias was graded as high, low, or unclear based on criteria described in the Cochrane Handbook for Systematic Reviews of Interventions 5.1.0. ${ }^{11}$ Furthermore, the Newcastle-Ottawa scale was used to assess the risk bias of the selected non-RCT studies (prospective, retrospective, and clinical human studies). The Newcastle-Ottawa scale is based on 3 major components: selection, comparability, and outcome for cohort studies. According to that quality scale, a maximum of 9 stars can be given to a study, representing the highest quality. ${ }^{13}$ Five or fewer stars represents a high risk of bias, whereas 6 or more stars represents a low risk of bias. ${ }^{13}$

The meta-analysis was based on the Mantel-Haenszel and inverse variance methods. Implant failure was the dichotomous outcome measure evaluated. Marginal bone loss was the continuous outcome measure evaluated for mean differences and the corresponding 95\% confidence intervals for both. When statistically significant $(P<.10)$ heterogeneity was detected, a random-effects model was used to assess the significance of treatment effects. When no statistically significant heterogeneity was found, the analysis was performed using a fixed-effects model. ${ }^{14,15}$ The risk ratio values were considered significant at $P$ less than .05. A software program (Reviewer Manager 5; Cochrane Group) was used for the meta-analysis and to elaborate the funnel plots.

An asymmetrical funnel plot may indicate publication bias or other biases related to sample size, although the asymmetry may also show a true relationship between trial size and effect size. ${ }^{16}$ The heterogeneity was assessed using the $\mathrm{Q}$ method $\left(x^{2}\right)$ and the value of $I^{2} .{ }^{17}$ The outcomes were dichotomized into good and poor results. $I^{2}$ values above 75 (range $=0-100$ ) were considered to indicate significant heterogeneity. ${ }^{17}$

To analyze the sensitivity of the tests used, a subgroup analysis was performed to identify any potential causes of heterogeneity. Specifically, the subgroups considered were splinting in internal connection, splinting in external connection, and splinting in posterior area. The outcomes accessed were marginal bone loss and implant failure.

The kappa statistic was calculated to define the interreader agreement in the study selection process. According to Landis and Koch, ${ }^{18}$ the level of interreader agreement is almost perfect if the value of kappa $(\kappa)$ is 0.81 to 1.00 , substantial if $\kappa$ is 0.61 to 0.80 , moderate if $\kappa$ is 0.41 to 0.60 , fair if $\kappa$ is 0.21 to 0.40 , and poor if $\kappa$ is less than 0.20 .

\section{RESULTS}

A search of the databases retrieved 894 references (Fig. 1). Applying the inclusion/exclusion criteria to the titles and abstracts of the selected comparative studies left 20 studies $(\kappa=0.95) \cdot{ }^{4,5,19-36}$ Upon reading the full texts, 1 study ${ }^{35}$ was excluded because it did not report information about crestal bone loss, implant survival, or prosthetic complications of splinted and nonsplinted implants. Details of the search strategy are presented in a flow diagram (Fig. 1).

A total of 19 studies ${ }^{4,5,19-34,36}$ were selected for qualitative and quantitative analyses. One was an RCT, ${ }^{4} 7$ were prospective clinical trials, $, 19,21,24-26,34$ and 11 were retrospective studies. ${ }^{20,22,23,27-33,36}$ A total of 4215 implants were placed in 2185 patients (splinted, 2768; nonsplinted, 1447) with a mean age of 51.4 years old; 6 studies did not report the mean age. ${ }^{25-28,32,33}$ The mean follow-up was 87.8 months (range $=12-264$ months). The main findings of these studies are presented in Tables 1 and 2. Six studies reported the use of only external connection implants, 4,19,20,21,24,28 7 studies reported the use of internal connection implant, $, 522,25-$ 27,29,36 1 study used both connections, ${ }^{31} 1$ study $^{34}$ used 1-piece implants, and 4 studies did not specify the connection. ${ }^{23,30,32,33}$

Marginal bone loss was evaluated in 9 studies. 4, $2,21,22,24,30,31,33,36$ Quantitative analysis found no significant differences between splinted and nonsplinted restorations ( $P=.32, I^{2}=79 \%$ ) (Fig. $2 \mathrm{~A}$ ). Also, the quantitative analysis of marginal bone loss found no significant differences between splinted and nonsplinted restorations for external connection implants $\left(P=.90, I^{2}=83 \%\right)$ (Fig. 2B) $)^{4,21,24,31}$ and internal connection implants $(P=.27$, $I^{2}=58 \%$ ) (Fig. 2C). $5,22,31,36$ Five studies reported information exclusively about marginal bone loss of implants placed in the posterior area. $4,24,31,36$ In this context, no statistical differences were found between splinted and nonsplinted restorations ( $P=.76, I^{2}=74 \%$ ) (Fig. 2D).

The assessed studies reported that 75 implants failed (3.4\%), of which 24 were splinted (99.1\% of survival rate) and 51 were nonsplinted ( $96.5 \%$ of survival rate) (Table 1 ). Eleven studies reported information about failures during their follow-up periods. 4, $5,19,20,23,25-27,31,32,34$ Quantitative analysis of all studies showed statistically significant higher survival rates for splinted restorations than nonsplinted restorations $(P<.001$, $I^{2}=0 \%$ ) (Fig. 3A).

Four studies reported implant failure for external implant connection, $, 19,20,31$ and 5 studies reported implant failure for internal connection. 5,25,26,27,31 For external connection implants, splinted restorations showed statistically significant higher survival rates than nonsplinted restorations $\left(P<.001, I^{2}=0 \%\right)$ (Fig. 3B). In contrast, no significant differences between splinted and nonsplinted restorations were found for internal connection implants $\left(P=.11, I^{2}=0 \%\right)$ (Fig. 3C). Seven studies reported failure in the posterior area. ${ }^{4,5,23,25,26,31,32}$ The quantitative analysis showed statistically significant higher survival rates for splinted restorations than nonsplinted restorations $(P=.009$, 


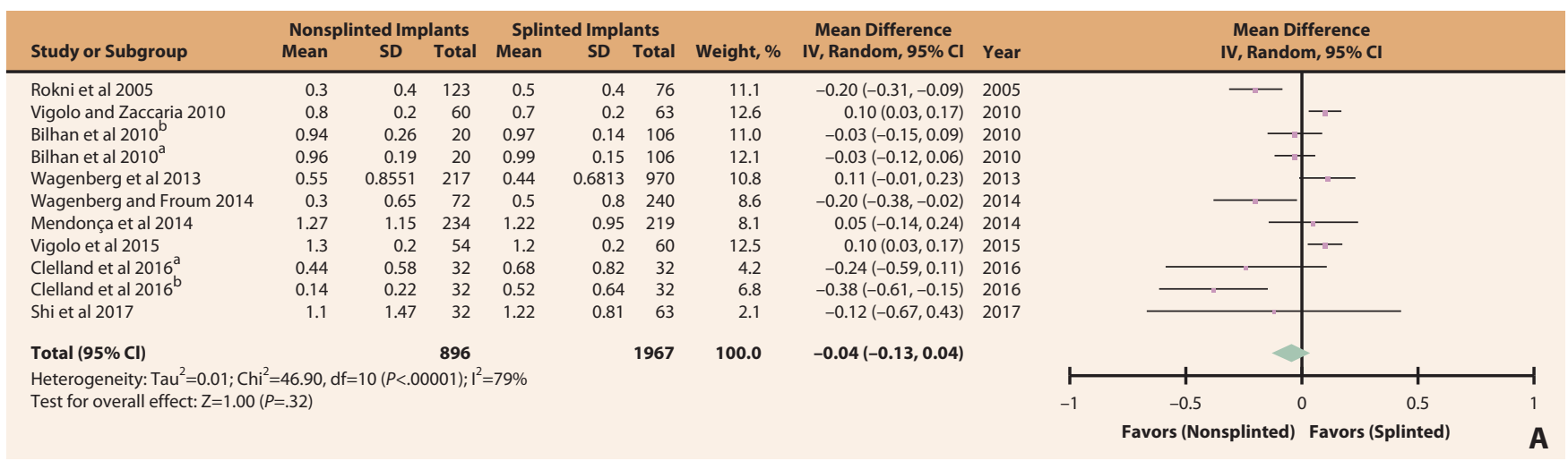

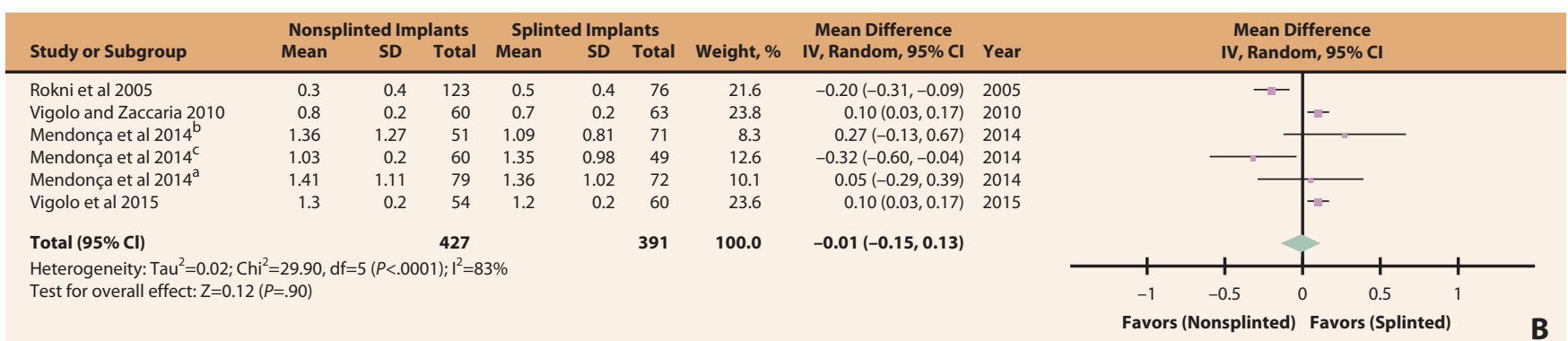

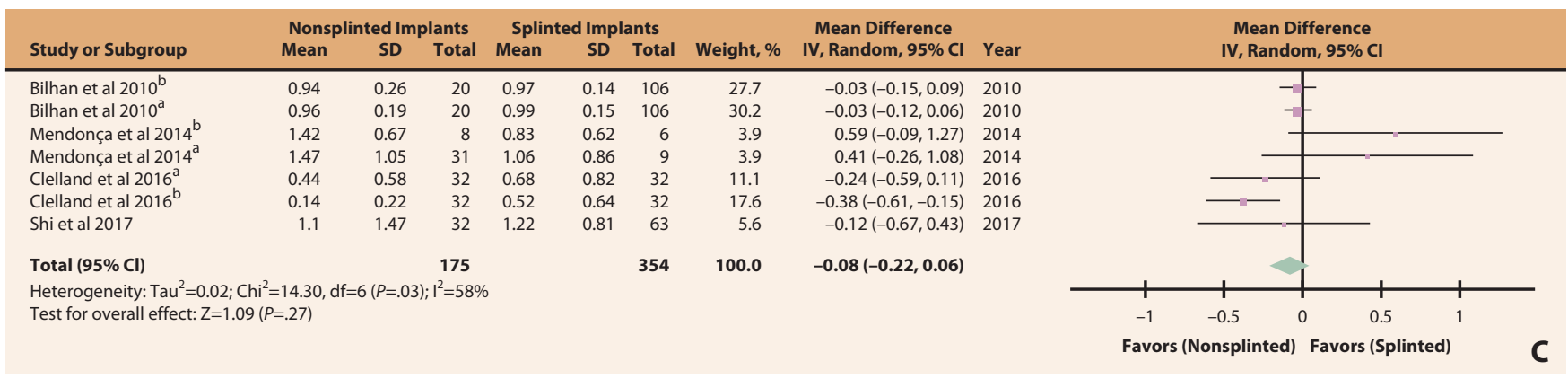

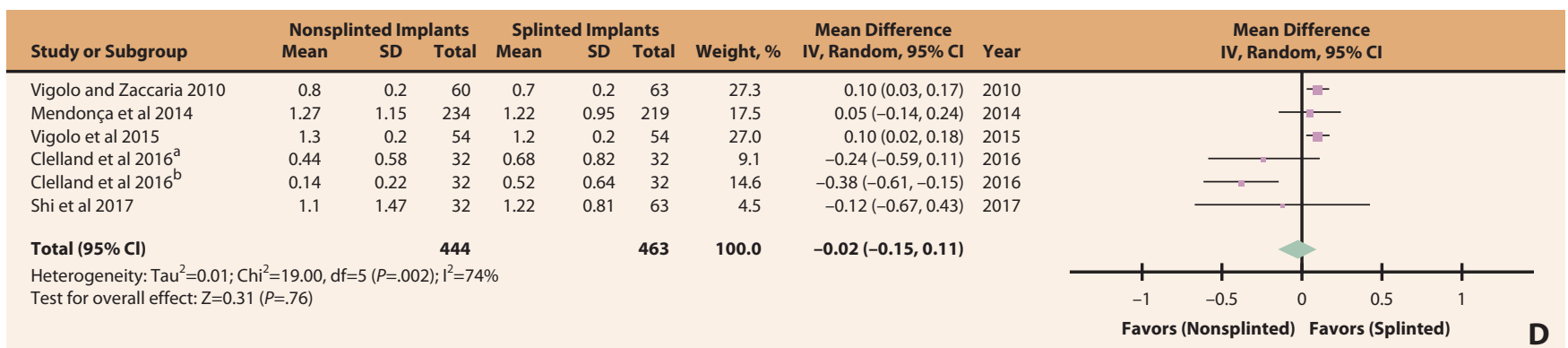

Figure 2. Forest plots. A, Comparison of marginal bone loss between splinted and nonsplinted restorations. B, Comparison of marginal bone loss between splinted and nonsplinted restorations in external connection implants. C, Comparison of marginal bone loss between splinted and nonsplinted restorations in internal connection implants. $\mathrm{D}$, Comparison of marginal bone loss between splinted and nonsplinted restorations in posterior area. $\mathrm{Cl}$, confidence interval; IV, inverse variance; SD, standard deviation.

$\left.I^{2}=0 \%\right)$ (Fig. 3D). The comparison between splinted and nonsplinted restorations in the anterior area was not possible because of insufficient data.

Ten studies reported information about prosthetic complications, ${ }^{4,5,21,22,24,26,28,29,34,36}$ including ceramic chipping, screw loosening, abutment screw breakage, and soft tissue inflammation. The most common prosthetic complications were ceramic chipping for splinted implants ${ }^{5,28,29,36}$ and for screw loosening $5,28,36$ and ceramic chipping ${ }^{28,29,36}$ for nonsplinted implants. The 


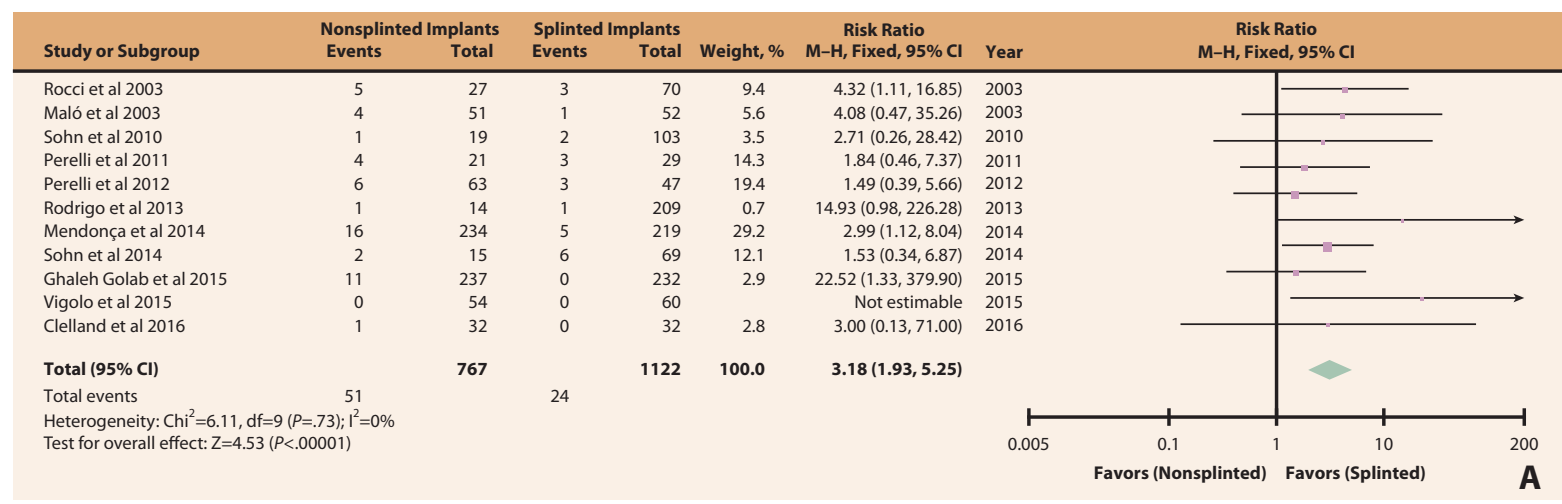

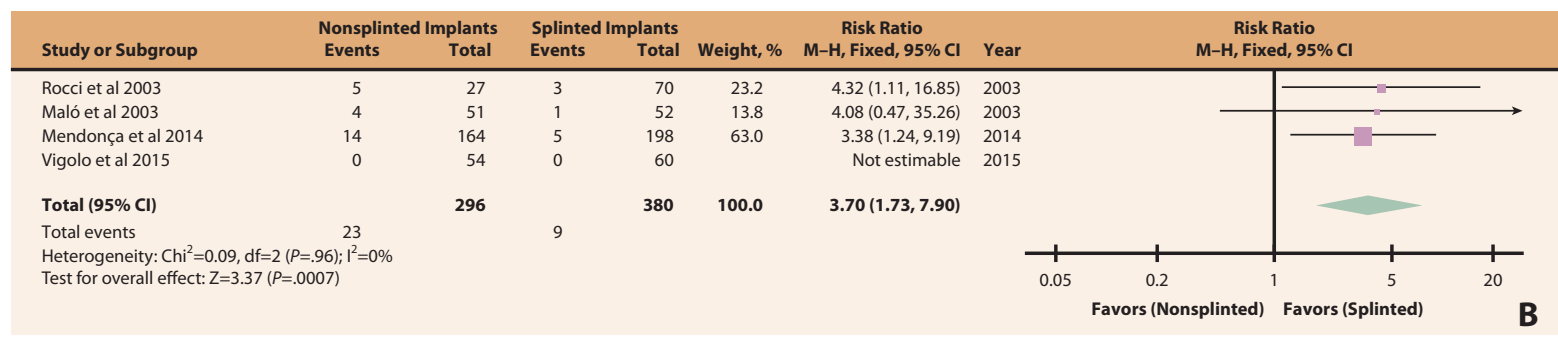

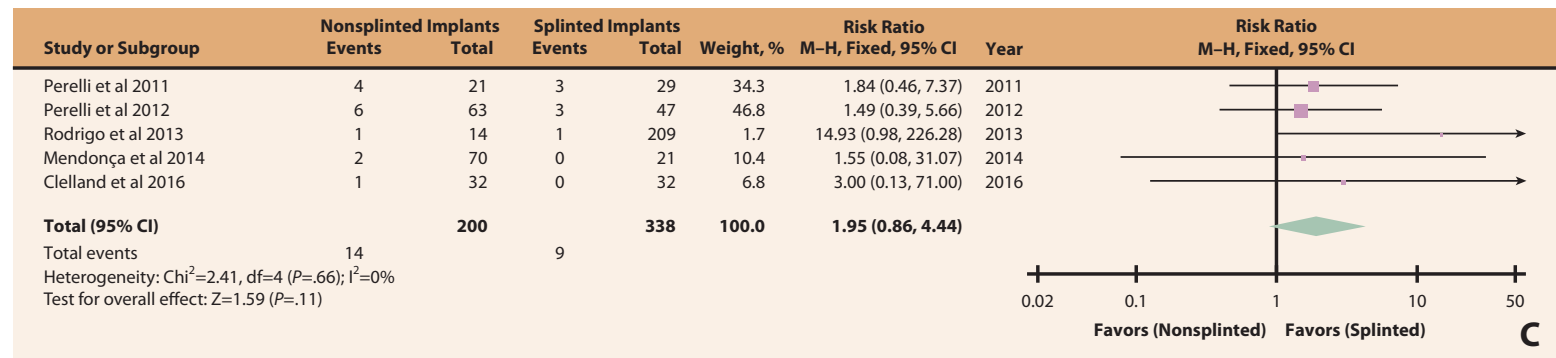

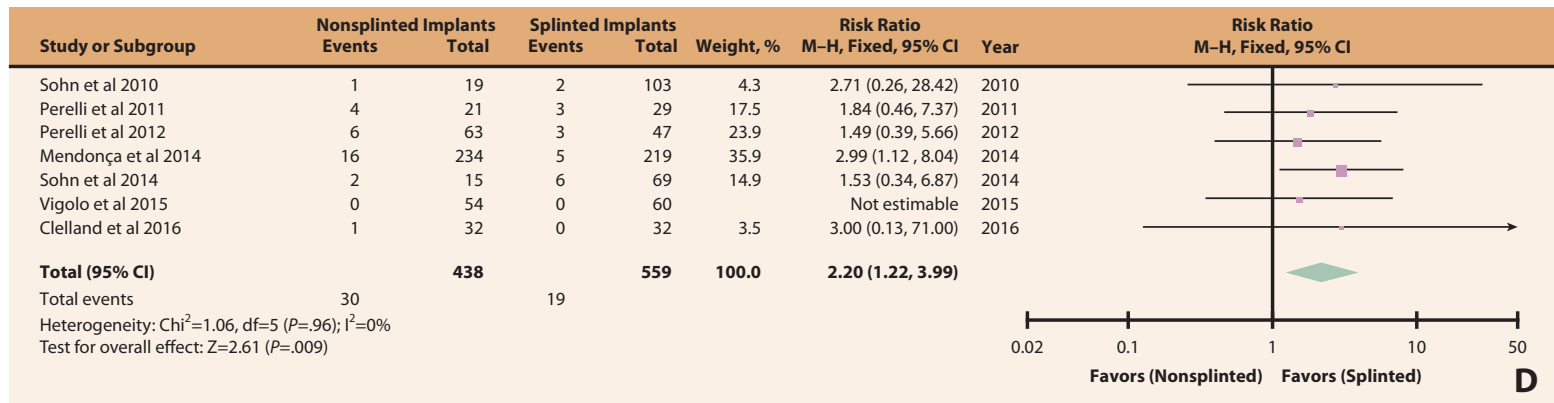

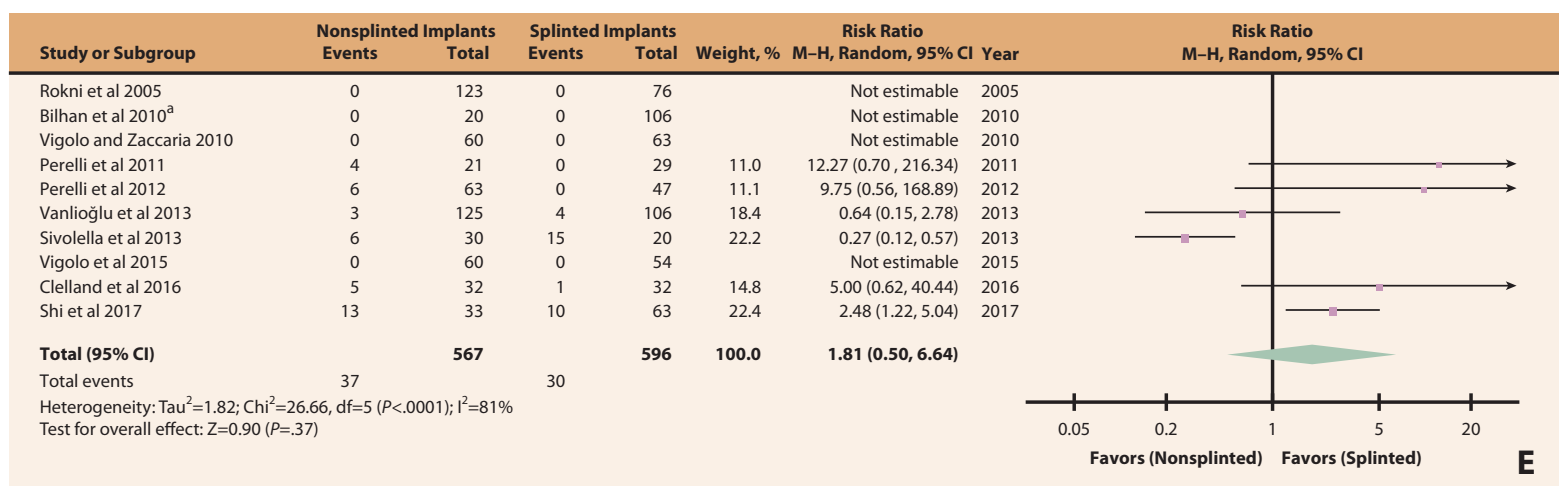

Figure 3. Forest plot. A, Comparison of implant failure between splinted and nonsplinted restorations. B, Comparison of implant failure between splinted and nonsplinted restorations in external connection implants. C, Comparison of implant failure between splinted and nonsplinted restorations in internal connection implants. D, Comparison of implant failure between splinted and nonsplinted restorations in posterior area. $E$, Comparison of prosthetic complications between splinted and nonsplinted restorations. $\mathrm{Cl}$, confidence interval; $\mathrm{M}-\mathrm{H}$, Mantel-Haenszel. 

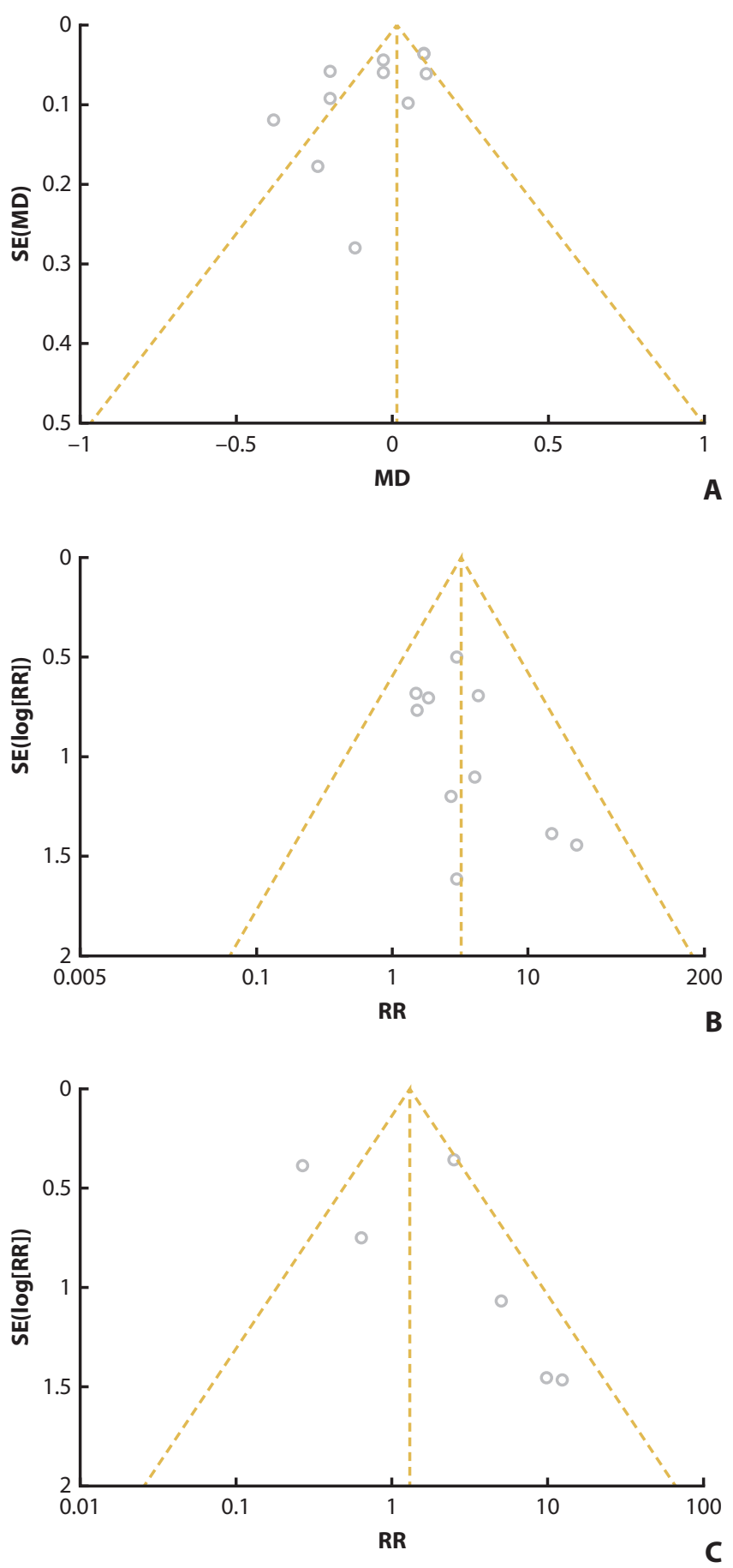

Figure 4. Funnel plots for assessment of publication bias: outcomes. A, Peri-implant bone loss. B, Implant failure. C, Prosthetic complication. MD, mean difference; $\mathrm{RR}$, risk ratio; $\mathrm{SE}$, standard estimates.

quantitative analysis found no statistically significant difference between splinted and nonsplinted restorations for prosthetic complications $\left(P=.37, I^{2}=81 \%\right)$ (Fig. 3E).

The funnel plot showed asymmetry in relation to the mean differences of the studies analyzed for marginal bone loss (Fig. 4A); however, symmetry of the funnel plot was shown for the implant failure analysis (Fig. 4B). For prosthetic complications, the funnel plot also showed asymmetry (Fig. 4C).

To assess the risk of bias in randomized trials, only 1 study ${ }^{4}$ was selected (Supplemental Table 1). Of the 18 non-RCT studies, 4 studies ${ }^{20,22,28,36}$ showed 9 stars and 12 studies showed 8 stars, $, 19,21,23-27,29,30,32-34$ representing a low risk of bias. The absence of stars was related mainly to "outcome of interest not present at start" (Supplemental Table 2).

\section{DISCUSSION}

The decision to splint or not generally occurs during the planning stage, when the advantages and disadvantages of each clinical situation are considered based on the proposed treatment. However, minimal clinical evidence is available to help clinicians make this decision. ${ }^{5}$ Thus, the results of the current systematic review and metaanalysis may help clinicians define a rational plan of treatment.

Recently, Al Amri and Kellesarian ${ }^{37}$ published a systematic review to compare the crestal bone loss around splinted and nonsplinted adjacent implants. Six clinical studies were included, and the authors concluded that the adjacent implants restored with splinted and nonsplinted fixed restorations did not differ in terms of crestal bone loss. Similarly, the present systematic review did not find statistical difference for marginal bone loss; however, a statistical difference was found for implant survival rate, showing an advantage for splinted restoration. Thus, new information about the topic has been published, justifying a new systematic review.

Ease of hygiene has been reported by patients with nonsplinted restorations. ${ }^{5}$ In this context, the biggest difficulty in cleaning the prosthesis may be associated with the highest prevalence of peri-implantitis ${ }^{38}$; this accelerates the pattern of bone loss. ${ }^{39}$ In the current systematic review and meta-analysis, the quantitative analysis of marginal bone loss showed no significant differences between splinted and nonsplinted restorations; therefore, the first null hypothesis of this study was not rejected. Possibly this occurred because, to participate in the study, individuals agreed to an adequate maintenance protocol and appropriate oral hygiene. Thus, an adequate maintenance protocol is required for individuals with dental implants, mainly for splinted restorations, to avoid progressive marginal bone loss.

The second null hypothesis of this study was rejected, because implants supporting splinted restorations showed statistically significant higher survival rates than nonsplinted restorations. These data agree with studies that have reported a high survival rate for implants with splinted restorations. ${ }^{23,27,31,34}$ Mendonça et $\mathrm{al}^{31}$ suggest that single restorations in the posterior region could be more susceptible to high masticatory forces, increasing the risk of micromotion above physiologic limits. 
Therefore, splinted implants may be indicated in clinical situations where there is a biomechanical risk to reduce the forces on implants and their surrounding tissues. ${ }^{24}$

Splinted restorations showed statistically significant higher survival rates than nonsplinted restorations for external connection implants; in contrast, no significant differences between splinted and nonsplinted restorations were found for internal connection implants. The literature suggests that an external connection implant has more micromotion of the abutment during loading than an internal connection implant ${ }^{40,41}$; thus, splinting restorations retained by external connection implants may improve the stability of the system, decreasing the risk of implant failure. The increased stability of the internal connection implant is associated with the ability to reduce the stress transferred to the crestal bone. ${ }^{40,41}$ Therefore, its use with nonsplinted crowns might reduce the risk of implant failure. However, further clinical studies are required to clarify this issue.

Shi et $\mathrm{al}^{36}$ reported that the prosthetic complication rates (such as veneer ceramic chipping, framework fracture, abutment screw loosening or fracture, implant fracture, and loss of retention) of splinted restorations supported by narrow implants were significantly lower than those of single crowns $(15.4 \%$ versus $39.4 \%$, respectively). In disagreement with Shi et $\mathrm{al}^{36}$ the quantitative analysis of prosthetic complication performed in the current meta-analysis showed no statistically significant difference between splinted and nonsplinted restorations; therefore, the third null hypothesis of this study was not rejected. However, the qualitative analysis showed that the loss of retention occurred with more frequency in nonsplinted restorations. $5,28,36$ This might be because of the biomechanical differences between splinted and nonsplinted implants, ${ }^{8}$ in which the splinted restoration has tended to share load among the screw components of the restoration. 8,42,43 Clinically, the splinting of posterior implants could be beneficial for reducing loss of retention. ${ }^{5,36}$

To avoid indirect comparison, only studies that offered data of splinted and nonsplinted restorations were selected. As consequence, analysis of the effect of splinting on different implant diameters and lengths, maxilla versus mandible, anterior versus posterior, patients with bruxism, or type of antagonist was not possible. Another study limitation was the inclusion of only 1 RCT in the analysis ${ }^{4}$; consequently, the inclusion of prospective and retrospective studies generated heterogeneity in the sample. The study limitations were a consequence of limited literature on the topic, indicating the need for further RCTs to investigate splinting and its associations.

According to Vigolo and Zaccaria ${ }^{24}$ and Vigolo et $\mathrm{al}^{4}{ }^{4}$ nonsplinted restorations may be a better treatment option when superior esthetics is essential; however, the literature on the topic is scarce. In this context, the clinician's personal preference may influence the choice of treatment plan. Further research is necessary to clarify this scenario.

\section{CONCLUSIONS}

Within the limitations of this systematic review and meta-analysis, the following conclusions were drawn:

1. No difference was found in the marginal bone loss and prosthetic complication rates of splinted and nonsplinted implant restorations, especially in the posterior region.

2. However, splinted restorations were associated with a decreased rate of implant failure.

\section{REFERENCES}

1. Hasegawa T, Kawabata S, Takeda D, Iwata E, Saito I, Arimoto S, et al Survival of Brånemark System Mk III implants and analysis of risk factors associated with implant failure. Int J Oral Maxillofac Surg 2017;46:267-73.

2. Lemos CA, de Souza Batista VE, Almeida DA, Santiago Júnior JF, Verri FR Pellizzer EP. Evaluation of cement-retained versus screw-retained implant supported restorations for marginal bone loss: a systematic review and metaanalysis. J Prosthet Dent 2016;115:419-27.

3. Verri FR, Batista VE, Santiago JF Jr, Almeida DA, Pellizzer EP. Effect of crown-to-implant ratio on peri-implant stress: a finite element analysis. Mater Sci Eng C Mater Biol Appl 2014;45:234-40.

4. Vigolo P, Mutinelli S, Zaccaria M, Stellini E. Clinical evaluation of marginal bone level change around multiple adjacent implants restored with splinted and nonsplinted restorations: a 10-year randomized controlled trial. Int J Oral Maxillofac Implants 2015;30:411-8.

5. Clelland N, Chaudhry J, Rashid RG, McGlumphy E. Split-mouth comparison of splinted and nonsplinted prostheses on short implants: 3-year results. Int J Oral Maxillofac Implants 2016;31:1135-41.

6. Pellizzer E, Santiago J Jr, Villa L, de Souza Batista V, de Mello C, de Faria Almeida D, et al. Photoelastic stress analysis of splinted and unitary implant supported prostheses. Appl Phys B 2014;117:235-44.

7. Bergkvist G, Simonsson K, Rydberg K, Johansson F, Derand T. A finite element analysis of stress distribution in bone tissue surrounding uncoupled or splinted dental implants. Clin Implant Dent Relat Res 2008;10:40-6.

8. de Souza Batista VE, Verri FR, Almeida DA, Santiago Junior JF, Lemos CA, Pellizzer EP. Evaluation of the effect of an offset implant configuration in the posterior maxilla with external hexagon implant platform: a 3-dimensional finite element analysis. J Prosthet Dent 2017;118:363-71.

9. Solnit GS, Schneider RL. An alternative to splinting multiple implants: use of the ITI system. J Prosthodont 1998;7:114-9.

10. Vázquez Álvarez R, Pérez Sayáns M, Gayoso Diz P, García García A. Factors affecting peri-implant bone loss: a post-five-year retrospective study. Clin Oral Implants Res 2015;26:1006-14.

11. Higgins JPT, Green S, eds. Cochrane handbook for systematic reviews of interventions version 5.1.0 [updated March 2011]. The Cochrane Collaboration; 2011. Available from http://handbook.cochrane.org.

12. Moher D, Liberati A, Tetzlaff J, Altman DG. PRISMA Group preferred reporting items for systematic reviews and meta-analyses: the PRISMA statement. Int J Surg 2010;8:336-41.

13. Lemos CA, Verri FR, Batista VE, Júnior JF, Mello CC, Pellizzer EP. Complete overdentures retained by mini implants: a systematic review. J Dent 2017;57: 4-13.

14. Egger M, Smith GD, Altman DG. Systematic reviews in health care: metaanalysis in context. 2nd ed. London: BMJ Books; 2003. p. 23-42.

15. Chrcanovic BR, Albrektsson T, Wennerberg A. Turned versus anodised dental implants: a meta-analysis. J Oral Rehabil 2016;43:716-28.

16. Duval S, Tweedie R. Trim and fill: a simple funnel plot-based method of testing and adjusting for publication bias in meta-analysis. Biometrics 2000;56:455-63.

17. Santiago JF Jr, Batista VE, Verri FR, Honório HM, de Mello CC, Almeida DA, et al. Platform-switching implants and bone preservation: a systematic review and meta- analysis. Int J Oral Maxillofac Surg 2016;45:332-45.

18. Landis JR, Koch GG. The measurement of observer agreement for categorical data. Biometrics 1977;33:159-74. 
19. Maló P, Friberg B, Polizzi G, Gualini F, Vighagen T, Rangert B. Immediate and early function of Brånemark System implants placed in the esthetic zone: a 1-year prospective clinical multicenter study. Clin Implant Dent Relat Res 2003;1:37-46.

20. Rocci A, Martignoni M, Gottlow J. Immediate loading in the maxilla using flapless surgery, implants placed in predetermined positions, and pre fabricated provisional restorations: a retrospective 3-year clinical study. Clin Implant Dent Relat Res 2003;1:29-36.

21. Rokni S, Todescan R, Watson P, Pharoah M, Adegbembo AO, Deporter D. An assessment of crown-to-root ratios with short sintered porous-surfaced implants supporting prostheses in partially edentulous patients. Int J Oral Maxillofac Implants 2005;20:69-76.

22. Bilhan H, Mumcu E, Arat S. The role of timing of loading on later marginal bone loss around dental implants: a retrospective clinical study. J Oral Implantol 2010;36:363-76.

23. Sohn DS, Kim WS, Lee WH, Jung HS, Shin IH. A retrospective study of sintered porous-surfaced dental implants in restoring the edentulous posterior mandible: up to 9 years of functioning. Implant Dent 2010;19: 409-18.

24. Vigolo P, Zaccaria M. Clinical evaluation of marginal bone level change of multiple adjacent implants restored with splinted and nonsplinted restorations: a 5-year prospective study. Int J Oral Maxillofac Implants 2010;25: 1189-94.

25. Perelli M, Abundo R, Corrente G, Saccone C. Short (5 and $7 \mathrm{~mm}$ long) porous implant in the posterior atrophic mandible: a 5-year report of a prospective study. Eur J Oral Implantol 2011;4:363-8.

26. Perelli M, Abundo R, Corrente G, Saccone C. Short (5 and $7 \mathrm{~mm}$ long) porous implants in the posterior atrophic maxilla: a 5-year report of a prospective single-cohort study. Eur J Oral Implantol 2012;5:265-72.

27. Rodrigo D, Cabello G, Herrero M, Gonzalez D, Herrero F, Aracil L, et al. Retrospective multicenter study of 230 6-mm SLA-surfaced implants with 1 to 6-year follow-up. Int J Oral Maxillofac Implants 2013;28:1331-7.

28. Sivolella S, Stellini E, Testori T, Di Fiore A, Berengo M, Lops D. Splinted and unsplinted short implants in mandibles: a retrospective evaluation with 5 to 16 years of follow-up. J Periodontol 2013;84:502-12.

29. Vanlıŏlu B, Özkan Y, Kulak-Özkan Y. Retrospective analysis of prosthetic complications of implant-supported fixed partial dentures after an observation period of 5 to 10 years. Int J Oral Maxillofac Implants 2013;28: 1300-4.

30. Wagenberg BD, Froum SJ, Eckert SE. Long-term bone stability assessment around 1,187 immediately placed implants with 1 - to 22 -year follow-up. Int J Oral Maxillofac Implants 2013;28:605-12.

31. Mendonça JA, Francischone CE, Senna PM, Matos de Oliveira AE, SottoMaior BS. A retrospective evaluation of the survival rates of splinted and nonsplinted short dental implants in posterior partially edentulous jaws. J Periodontol 2014;85:787-94.

32. Sohn DS, Lee JM, Park IS, Jung HS, Park DY, Shin IH. Retrospective study of sintered porous-surfaced dental implants placed in the augmented sinus. Int J Periodontics Restorative Dent 2014;34:565-71.

33. Wagenberg B, Froum SJ. Long-term bone stability around 312 roughsurfaced immediately placed implants with 2-12-year follow-up. Clin Implant Dent Relat Res 2015;17:658-66.
34. Ghaleh Golab K, Balouch A, Mirtorabi S. One-year multicenter prospective evaluation of survival rates and bone resorption in one-piece implants. Clin Implant Dent Relat Res 2016;18:392-400.

35. Wang JH, Judge R, Bailey D. Five-year retrospective assay of implant treatments and complications in private practice: restorative treatment profiles of single and short-span implant-supported fixed prostheses. Int J Prosthodont 2016;29:372-80.

36. Shi JY, Xu FY, Zhuang LF, Gu YX, Qiao SC, Lai HC. Long-term outcomes of narrow diameter implants in posterior jaws: a retrospective study with at least 8-year follow-up. Clin Oral Implants Res 2018;29:76-81.

37. Al Amri MD, Kellesarian SV. Crestal bone loss around adjacent dental implants restored with splinted and nonsplinted fixed restorations: a systematic literature review. J Prosthodont 2017;26:495-501.

38. Schuldt Filho G, Dalago HR, Oliveira de Souza JG, Stanley K, Jovanovic S, Bianchini MA. Prevalence of peri-implantitis in patients with implantsupported fixed prostheses. Quintessence Int (Berl) 2014;45:861-8.

39. Derks J, Schaller D, Håkansson J, Wennström JL, Tomasi C, Berglundh T. Peri-implantitis-onset and pattern of progression. J Clin Periodontol 2016:43:383-8.

40. Gracis S, Michalakis K, Vigolo P. Vult von Steyern P, Zwahlen M, Sailer I. Internal vs. external connections for abutments/reconstructions: a systematic review. Clin Oral Implants Res 2012;6:202-16.

41. Goiato MC, Pellizzer EP, da Silva EV. Bonatto Lda R, dos Santos DM. Is the internal connection more efficient than external connection in mechanical, biological, and esthetical point of views? A systematic review. Oral Maxillofac Surg 2015;19:229-42.

42. Lemos CAA, Verri FR, Santiago JF Jr, Almeida DAF, Batista VES Noritomi PY, et al. Retention system and splinting on Morse taper implants in the posterior maxilla by 3D finite element analysis. Braz Dent J 2018;29: 30-5.

43. Pellizzer EP, de Mello CC, Santiago JF Jr, de Souza Batista VE, de Faria Almeida DA, Verri FR. Analysis of the biomechanical behavior of short implants: the photo-elasticity method. Mater Sci Eng C Mater Biol Appl 2015;55:187-92.

\section{Corresponding author:}

Dr Victor Eduardo de Souza Batista

Department of Dental Materials and Prosthodontics

São Paulo State University (UNESP), Araçatuba

José Bonifácio St, 1193

Araçatuba, São Paulo 16015-050

BRAZIL

Email: victor_edsb@hotmail.com

\section{Acknowledgments}

The authors thank professors Dr Leonardo Perez Faverani and Dr Aldiéris Alves Pesqueira for critical suggestions for the article.

Copyright $\odot 2018$ by the Editorial Council for The Journal of Prosthetic Dentistry. https://doi.org/10.1016/j.prosdent.2018.03.004 